This item was submitted to Loughborough's Research Repository by the author.

Items in Figshare are protected by copyright, with all rights reserved, unless otherwise indicated.

\title{
Expatriates, subsidiary autonomy and the overseas subsidiary performance of MNEs from an emerging economy
}

\author{
PLEASE CITE THE PUBLISHED VERSION
}

http://dx.doi.org/10.1080/09585192.2017.1284883

\section{PUBLISHER}

Taylor \& Francis

\section{VERSION}

AM (Accepted Manuscript)

\section{PUBLISHER STATEMENT}

This work is made available according to the conditions of the Creative Commons Attribution-NonCommercialNoDerivatives 4.0 International (CC BY-NC-ND 4.0) licence. Full details of this licence are available at: https://creativecommons.org/licenses/by-nc-nd/4.0/

\section{LICENCE}

CC BY-NC-ND 4.0

\section{REPOSITORY RECORD}

Tao, Fang, Xiaohui Liu, Lan Gao, and Enjun Xia. 2019. "Expatriates, Subsidiary Autonomy and the Overseas Subsidiary Performance of Mnes from an Emerging Economy”. figshare. https://hdl.handle.net/2134/22813. 
Expatriates, Subsidiary Autonomy and the Overseas Subsidiary Performance of MNEs from an Emerging Economy

\author{
Fang Tao $^{\mathrm{a}}$ \\ Xiaohui Liu ${ }^{\mathrm{a}^{*}}$ \\ Lan Gao ${ }^{\mathrm{a}}$ \\ ${ }^{a}$ School of Business and Economics \\ Loughborough University \\ Leicestershire, LE11 3TU \\ Enjun Xia \\ School of Management and Economics \\ Beijing Institute of Technology \\ Beijing 100081, P.R. China \\ Email: enjunxia@bit.edu.cn
}

* Corresponding author. Email: X.liu2@lboro.ac.uk 


\title{
Expatriates, Subsidiary Autonomy and the Overseas Subsidiary Performance of MNEs from an Emerging Economy
}

\begin{abstract}
Despite a growing body of research on the role of expatriates in subsidiary performance, the mechanisms through which expatriates affect subsidiary performance are still the subject of debate. Drawing on the resource dependence theory, we examine the indirect effect of expatriates on subsidiary performance via subsidiary autonomy based on a sample of Chinese multinational enterprises (MNEs). The findings show that an increase in expatriates reduces the level of subsidiary autonomy and thus negatively affects subsidiary performance. We also find that the institutional quality of host countries reinforces the negative impact of expatriates on subsidiary autonomy, but reduces the importance of the latter on subsidiary performance.
\end{abstract}

Keywords: Chinese MNEs, expatriates, subsidiary autonomy, institutional quality, subsidiary performance 


\section{Introduction}

Over recent decades, the influence of expatriates on subsidiary performance has been an important theme in international business and international human resource management (HRM) research (Colakoglu \& Caligiuri, 2008; Gaur, Delios, \& Singh, 2007; Gong, 2003a). The term expatriates in this study refers to parent country nationals from multinational enterprise (MNE) parent companies assigned to their foreign subsidiaries (Tan \& Mahoney, 2006). As one of the most important resources of MNEs, expatriates are expected to achieve a wide range of corporate objectives including facilitating firm-specific knowledge transfer (Jensen \& Szulanski, 2004; Wang, Tong, \& Koh, 2004), establishing international operations and opening new markets, as well as gaining international experience. These, in turn, help MNEs obtain competitive advantage and enhance their subsidiary performance (Delios \& Beamish, 2001; Tan \& Mahoney, 2006).

While the existing literature in this area has recognised the importance of expatriates for the subsidiary performance of MNEs, much research has focused on the performance benefits of expatriates from developed economy MNEs, such as the US, Europe and Japan, and has tended to assume that the knowledge to be transferred from headquarters to subsidiaries through expatriates positively affects subsidiary performance (Delios \& Beamish, 2001; Gong, 2003b; Tan \& Mahoney, 2006). However, in the past decade, outward foreign direct investment (FDI) from emerging economy MNEs (EEMNEs) has increased rapidly. The increasing presence of EEMNEs in the global market place has raised the question as to whether the findings on the relationship between expatriates and subsidiary performance based on established MNEs can be applied to EEMNEs. In particular, we know very little about 
the impact of internal control mechanisms through expatriates on subsidiary performance and whether such an impact is contingent on the institutional environment of host countries.

In addition, previous research on expatriation and subsidiary performance has overwhelmingly focused on the direct impact of expatriates on subsidiary performance through the lenses of transaction-cost economics (TCE) (Benito, et al., 2005; Colakoglu \& Caligiuri, 2008; Tan \& Mahoney, 2006) and institutional theory (Xu, Pan, \& Beamish, 2004) without considering the role of subsidiary autonomy. However, as an important internal strategic resource of MNEs, expatriates are supposed to carry out the mission of headquarters, and MNE parents may exert control over a subsidiary by adjusting the level of expatriates in host countries. Thus, expatriates not only affect knowledge transfer between the MNE parent and the subsidiary, but also subsidiary autonomy, which in turn influences subsidiary performance. Although the effect of subsidiary autonomy on subsidiary performance has become an important theme in international HRM research (Gammelgaard, et al., 2012; Gomez \& Werner, 2004; Kawai \& Strange, 2014; McDonald, Warhurst, \& Allen, 2008; Slangen \& Hennart, 2008), the mediating role of subsidiary autonomy in the relationship between the level of expatriates and subsidiary performance has been under-explored, especially in the case of EEMNEs. It is important to delineate the path from expatriates to subsidiary performance via subsidiary autonomy in host countries with different institutional environments, given that EEMNEs originated in under-developed institutional environments and they may respond to the institutional environments of host countries through altering internal control systems such as expatriate staffing and subsidiary autonomy. Thus, the link between expatriates, 
subsidiary autonomy and subsidiary performance may be contingent on the institutional environment of a host country.

To address the research gaps, we adopt the resource dependence perspective (Pfeffer \& Salancik, 1978) to examine the following research questions. To what extent does subsidiary autonomy mediate the impact of expatriates on subsidiary performance? To what extent does host-country institutional quality moderate the relationship between expatriates and the subsidiary performance of EEMNEs? We propose that subsidiary autonomy may act as an intermediate factor between expatriates and subsidiary performance given the institutional quality of host countries.

We chose China as our research setting due to the rapid growth of Chinese outward FDI, with an average annual growth rate of almost 50\% (WIR, 2014). China's outward FDI was only $\$ 12$ billion in 2005, but reached $\$ 77.2$ billion in 2012, which accounted for approximately 61\% of outbound FDI from emerging economies. China's outward FDI overtook inward FDI in 2014 making China a net capital exporter for the first time. The new 'One Belt One Road' strategy announced in September 2013, the establishment of the Asian Infrastructure Investment Bank (AIIB) and the Silk Road fund will continue to encourage large scale outward investment. These aspects indicate that China can serve as an appropriate and important empirical setting where we can examine the factors affecting EEMNEs' overseas operations. It is also timely to study the impact of the subsidiary control strategies adopted by Chinese MNEs that have heavily invested in a wide range of host countries with varying degrees of institutional quality.

This study extends the existing literature on expatriation and subsidiary performance in general, and EEMNEs in particular in three main ways. First, our research extends resource dependence theory (RDT) in order to understand the extent 
to which subsidiary autonomous strategies mediate the influence of expatriation on subsidiary performance. The findings from this study provide new insights into the mediating mechanism of subsidiary autonomy and move beyond previous studies which have mainly focused on the direct impact of expatriation on subsidiary performance without considering the mediation role of subsidiary autonomy. Second, we further extend the existing research by examining the moderating role of hostcountry institutional quality on the relationship between expatriates and subsidiary performance. The findings shed new light on the institutional conditions under which expatriates affect subsidiary performance, and add much needed empirical evidence regarding the interrelationship between internal control mechanisms and EEMNEs' overseas performance. Finally, while much existing literature in this domain is based on MNEs from advanced economies, our study is one of the first to systematically investigate the relationships among expatriation, subsidiary autonomy and the subsidiary performance of EEMNEs. In doing so, we advance existing research by capturing the complex linkage between EEMNE parents and their subsidiaries through expatriates and subsidiary autonomy. Specifically, EEMNEs parents adjust the level of expatriates and subsidiary autonomy to reduce external dependence in host countries with underdeveloped institutions, and engage in knowledge exploration in the countries with high institutional quality.

This paper is structured as follows: The next section focuses on theory and hypotheses. We then introduce the sample and variables used in the study in Section 3. Section 4 presents the empirical results, followed by discussion of the findings and highlighting of the contributions. Section 6 concludes.

\section{Theory and Hypotheses}




\section{Theoretical Background}

The extant literature has used multiple theories to examine the optimal level of expatriates, such as institutional theory (Xu, Pan, \& Beamish, 2004), transaction-cost economics (TCE) (Benito, et al., 2005; Colakoglu \& Caligiuri, 2008; Tan \& Mahoney, 2006) and resource-based theory (Tan \& Mahoney, 2006). The findings from existing studies have enhanced our understanding of the importance of expatriates in MNEs' overseas operations. However, these studies have paid little attention to the impact of expatriates on subsidiary autonomy (Aharoni, Tihanyi, \& Connelly, 2011) and how EEMNEs respond to external uncertainty by adjusting their internal management strategies (Davis \& Cobb, 2010), such as the levels of localisation (Liu, et al., 2016; Lu, et al., 2014; Yildiz \& Fey, 2012) and parental support (Feinberg \& Gupta, 2009; Luo, 2003). The resource dependence theory (RDT) has been increasingly influential as a theoretical basis for international business research. For example, Lewin et al. (2004) suggest that the RDT is a particularly appropriate approach and helps to account for the dynamic relationship between an MNE parent and its subsidiaries. Thus, this study takes an overarching theoretical view of RDT to examine the indirect impact of expatriates on subsidiary performance via subsidiary autonomy.

RDT considers the behaviour aspect of firms and explains the importance of intra and inter-organisational behaviour based on power relationships (Pfeffer \& Salancik, 1978). According to RDT, a host country is endowed with scarce resources needed by MNE subsidiaries (Cui, Meyer, \& Hu, 2014; Moran, 1985), and a dependency situation arises when MNE subsidiaries rely on irreplaceable resources controlled by local resource holders (Pfeffer \& Salancik, 1978). In particular, when local institutions are underdeveloped, MNE subsidiaries face increasing risk and uncertainty due to ambiguous regulations and perhaps an unstable government. In 
order to decrease the risk or transaction costs associated with resource acquisition, an MNE subsidiary can reduce its dependence on local resources by utilizing more internal resources possessed by its parent (Kobrin, 1982). This internal flow may consist of not only physical resources but also knowledge and human resources (Gupta \& Govindarajan, 1991). Thus, the improvement of resource support from MNE parents may help to reduce the external dependency of the subsidiaries.

Expatriates constitute an important internal resource within MNEs and the utilisation of expatriates influences the parent-subsidiary relationship (Fang, et al., 2010). An MNE parent may assign expatriates to the subsidiary as a specific governance mechanism (Gong, 2003b). This internal control mechanism helps ensure a subsidiary's compliance with the parent company's organisational values and operational priorities (Belderbos \& Heijltjes, 2005; Boyacigiller, 1990). In addition, expatriates can play a key role in facilitating the transfer of firm-specific tacit and complex knowledge from a parent to its subsidiary, particularly for recently established foreign subsidiaries (Delios \& Bjorkman, 2000; Wang, et al., 2009). Through the formal communication channel and the informal socialisation mechanism, expatriates can identify, access and bring relevant parent knowledge to the subsidiary (Edstrom \& Galbraith, 1977). This knowledge may include corporate culture, management styles and ways of conducting business which create causal ambiguity and barriers to transfer and imitation (Simonin, 1999). Therefore, an MNE parent will have substantial control over its subsidiary through expatriates. The subsidiary in turn will rely on its parent for resources and knowledge in order to minimise risk and external dependence in host countries with low quality institutions. This suggests that expatriates may serve as an internal control mechanism for an MNE parent and affect subsidiary autonomy, which in turn impacts on subsidiary performance (McDonald, 
Warhurst, \& Allen, 2008). This implies that the effect of expatriates on organizational outcomes is more complex than the existing literature suggests. Therefore, this study focuses on the indirect impact of expatriates on subsidiary performance via subsidiary autonomy.

As shown in Figure 1, we propose that expatriates have a negative impact on subsidiary autonomy, and a reduction in subsidiary autonomy leads to a decrease in subsidiary performance. Furthermore, institutional quality in the host country positively moderates the first link (i.e. the relationship between expatriates and subsidiary autonomy), but negatively moderates the second link (i.e. subsidiary autonomy and subsidiary performance) in the mediation relationship. In other words, subsidiary autonomy mediates the relationship between expatriates and subsidiary performance, given the institutional quality of the host countries. Taken together, we propose a moderated mediation model to capture the complex relationships between expatriates, subsidiary autonomy and subsidiary performance, given different levels of institutional quality.

\section{INSERT FIGURE 1 NEAR HERE}

\section{The Mediating Role of Subsidiary Autonomy}

Subsidiary autonomy is a complex concept (Young \& Tavares, 2004) which is commonly defined as the extent to which a subsidiary has the authority to make decisions with a degree of independence from the MNE parent (Brooke, 1984; Nell \& Andersson, 2012; O'Donnell, 2000). If a subsidiary can make decisions on main value activities, such as HRM, procurement, marketing and sales (Browman, Duncan, \& Weir, 2000; Edwards, Ahmad, \& Moss, 2002), and enjoy higher levels of decision- 
making power for these value activities (Newburry, Zeria, \& Yeheskel, 2003), it will have more autonomy.

A growing body of existing literature has established that subsidiary autonomy serves as a mechanism for management control, which affects subsidiary performance. For instance, McDonald, Warhurst and Allen (2008) find that there is a positive relationship between various degrees of subsidiary autonomy and performance. Ambos and Birkinshaw (2010) indicate that subsidiaries achieve superior performance by enjoying high levels of local decision-making authority, and by attracting the parent company's attention within the MNE network. Tran et al. (2010) suggest that subsidiary autonomy is an important element of MNE strategies and is positively associated with subsidiary performance. Similarly, Gammelgaard et al. (2012) present evidence that subsidiary performance is increased with subsidiary autonomy. Kawai and Strange (2014) also suggest that the appropriate balance between subsidiary internal and external factors can help a subsidiary to achieve superior performance. Wang, et al., (2014) find that subsidiary autonomy is considered a strategic mechanism to overcome EEMNEs’ lack of experience in managing globally dispersed businesses and home-country disadvantages. However, little research has systematically examined the relationship between expatriates and subsidiary autonomy, as well as the question of whether the autonomy granted to a foreign subsidiary will mediate the relationship between expatriates and subsidiary performance.

We propose that in addition to the direct impact of expatriates on subsidiary performance, there may be the indirect impact of expatriates on subsidiary performance via subsidiary autonomy. Drawing upon the RDT, expatriates, as valuable human resources, are considered an internal control mechanism to reduce 
external dependence (Chalos \& O'Connor, 2004). Assigning expatriates is an important way for the headquarters to exercise its power (Gupta \& Govindarajan, 1991). In order to process a substantial amount of information regarding subsidiary operating protocols, an MNE parent usually assigns expatriate managers whose function will be to increase the channels of communication between the parent company and the subsidiary, which guarantees that the parent company's interests are well represented within the subsidiary (Boyacigiller, 1990). Expatriates and subsidiary autonomy are closely related to each other. As expatriates can be considered an extended form of headquarters control and supervision (Boyacigiller, 1990; Egelhoff, 1984; Lorange, 1986; Steers \& Nardon, 2006), subsidiary autonomy will become lower when the level of expatriates is higher.

On the other hand, a reduction in subsidiary autonomy may reduce subsidiary performance due to more limited access to valuable external resources which are available locally in host countries. Extant research shows that subsidiary autonomy granted by MNE parents has a positive impact on subsidiary performance (Gammelgaard, et al., 2012; Gomez \& Werner, 2004; McDonald, Warhurst, \& Allen, 2008). Most existing research has argued that less autonomy will discourage the subsidiary from fostering a higher level of organisational learning (Luo, 2003), reduce parent-subsidiary cooperation (Birkinshaw, et al., 2000), block knowledge creation (Young \& Tavares, 2004) and hinder strategic leadership initiatives (Birkinshaw, Hood, \& Jonsson, 1998). All of these reduce competitive advantages, decreasing subsidiary performance. More importantly, a lower level of autonomy may block or represent barriers to the access to complementary external resources in host countries. For example, operational costs will be significantly increased where companies do not work with local suppliers or embed subsidiaries within the local supply network (Fan, 
Nyland, \& Zhu, 2008; Rangan \& Drummond, 2011). The subsidiaries with limited autonomy find it difficult to bond and cooperate with local businesses without the involvement of local managers and employees who have better knowledge of local market environments than expatriates (Law, et al., 2009; Selmer, 2004). This will in turn negatively influence subsidiary performance.

In summary, adopting RDT logic, subsidiary autonomy serves as an intermediate mechanism through which expatriates can affect subsidiary performance. Therefore, departing from the existing research in this domain, we posit a mediation path that moves beyond the direct impact of expatriates on subsidiary performance. That is, using expatriates can enable the parent company to have tighter control on subsidiaries and thus reduce subsidiary autonomy, which in turn leads to a decrease in subsidiary performance. Hence, we hypothesise:

Hypothesis 1: Subsidiary autonomy mediates the relationship between expatriates and subsidiary performance in that the level of expatriates has a negative impact on subsidiary autonomy, and a reduction in subsidiary autonomy leads to a decrease in subsidiary performance.

\section{The moderating role of host-country institutional quality}

The institutional quality of host countries has long been identified as an important factor affecting MNE subsidiary performance (Liu, et al., 2016; Luo \& Tung, 2007). It refers to the degree of stability and development of the institutional infrastructure of host countries, which includes the set of laws, regulations, administrative procedures and policies formally sanctioned by the government (Cuervo-Cazurra \& Genc, 2008; Delios \& Henisz, 2003). The existing research reveals that knowledge is more likely to be obtained and learned from a host country with well-established institutions 
where effective institutional protection can be provided for foreign firms operating there (Berry, 2006; Buckley, et al., 2010; Luo \& Tung, 2007). EEMNEs that lack international managerial expertise, international market knowledge and advanced technology may be able to acquire these strategic assets when their subsidiaries are located in host countries with well-developed institutions. Local firms in these host countries are more likely to possess strategic resources needed by EEMENs, but such resources are not usually available in the EEMNEs' domestic markets or in other emerging markets (Nicholson \& Salaber, 2013). The asset-seeking behaviour of EEMNEs may reduce the dependence of their subsidiaries on headquarters in such host countries ( $\mathrm{Lu}$, et al., 2014). This in turn may reduce the need for expatriates compared to those subsidiaries in host countries with underdeveloped institutions which offer limited opportunities for knowledge exploration. The reduced level of expatriates also lessens the control from the corporate parent. This implies that a higher autonomy may be achieved by a subsidiary located in those host countries with high institutional quality, and thereby gain access to strategic resources and advanced knowledge available locally, and hence reduce transaction costs. Thus, the negative relationship between expatriates and subsidiary autonomy will be reinforced in those host countries with well-established institutions.

In contrast, when host-country institutions are underdeveloped, the institutional environment tends to be risky (Wang, et al., 2014). EEMNEs operating within such an environment are subject to increasing external uncertainty and decreasing credibility (Agarwal \& Ramaswami, 1992; Akhter \& Lusch, 1998; Delios \& Beamish, 1999; Delios \& Henisz, 2000; Henisz, 2000). According to RDT, a subsidiary relies more on the internal resources and knowledge transferred from MNE headquarters in order to replace inter-organizational resource exchanges (Feinberg \& 
Gupta, 2009). Expatriates can be used as an internal resource to reduce the external dependence when facing uncertainty stemming from the unstable external environment. Thus, an increasing level of expatriates may become a pragmatic response strategy when EMNE subsidiaries operate in such host countries (i.e. those with institutional ambiguities, underdeveloped markets and ineffective enforcement of regulations) (Wright, et al., 2005). When uncertainty in business activities is high in a host country, centralised subsidiaries are unlikely to overcome the frequent changes and unknowns inherent in environmental uncertainty due to a high level of bureaucracy in the decision making process as well as the coordination costs associated with a high level of centralization (Bartlett \& Ghoshal, 1989). This implies that extra autonomy needs to be granted to respond promptly to frequent changes resulting from increasing external uncertainty. As a result, an increase in expatriates from headquarters may lead to a disproportionate decrease in subsidiary autonomy when subsidiaries operate in an underdeveloped institutional environment, given that subsidiaries in such an environment need more internal resource exchange and a higher level of subsidiary autonomy to respond to institutional voids. Hence, we propose:

Hypothesis 2: Host-country institutional quality will influence the negative impact of expatriates on subsidiary autonomy such that the negative relationship between expatriates and subsidiary autonomy is stronger in host-countries with high institutional quality than those with low institutional quality.

Institutional quality in host countries not only moderates the link between expatriates and subsidiary autonomy, but also the relationship between subsidiary autonomy and subsidiary performance. Since institutions are developed to create order 
and a stable environment, and to promote economic exchange and cooperation (North, 1990; Williamson, 1985), host-country institutions affect the ability of subsidiaries to access external resources and knowledge (Meyer \& Sinani, 2009). Well-established institutions are able to provide an efficient common infrastructure and reduce transactional uncertainty (McEvily \& Zaheer, 1999). Foreign subsidiaries operating in host countries with high institutional quality can easily follow 'the rules of the game' and gain the information necessary for effective operations (Schwens, Eiche, \& Kabst, 2011). In addition, well-developed market-supporting institutions may help subsidiaries reduce the search costs associated with accessing critical knowledge and resources for foreign operations. This indicates that political risks and uncertainty are relatively low in host countries with well-developed institutions, so the importance of subsidiary autonomy for subsidiary performance may be reduced when operating in such a context. This implies that a high level of subsidiary autonomy may not be a necessary condition for achieving desirable performance.

On the other hand, under-developed institutions generate hazards of expropriation and transactional uncertainty. Subsidiaries have to rely on greater autonomy to deal with political and operational risks. Therefore, subsidiary autonomy can have a more positive impact on its performance when a subsidiary has the flexibility to respond to frequent changes and instability in host countries with low quality institutions. An 'agile' approach with regard to local decision making may be necessary in order to cope with frequent decision making cycles. Such a mechanism can help to ensure effective operations, thus enhancing subsidiary performance. Extant research shows that uncertainty in a turbulent environment strengthens the positive relationship between autonomy and subsidiary profitability (Andersen, 2005; Kawai \& Strange, 2014). This suggests that the positive impact of subsidiary 
autonomy on subsidiary performance will be stronger in host countries with underdeveloped institutions. Our argument above lead to the following hypothesis:

Hypothesis 3: Host-country institutional quality will influence the positive impact of subsidiary autonomy on subsidiary performance such that the positive relationship between subsidiary autonomy and subsidiary performance is stronger in host countries with low institutional quality than those with high institutional quality.

\section{Methodology}

\section{Sample and Data Collection}

The data used to test the hypotheses was collected with support from the Asia Pacific Foundation of Canada (APFC) and the China Council for the Promotion of International Trade (CCPIT). The former is an independent non-governmental organisation focusing on Canada's relations with Asia, while the latter is a national non-government organisation for the promotion of foreign trade in China. Collaboration with the CCPIT enabled us to access members through its local representatives who are familiar with these enterprises, and thus encourage participation in the survey.

On the basis of a thorough literature review, the questionnaire was originally prepared in English and then, with the assistance of an independent translator, translated into Chinese. Following Hoskisson, et al. (2000), we examined the accuracy of the survey content through a back-translation technique. We also conducted four in-depth interviews with CCPIT officials to cross-check questionnaire items and terminology, and to ratify the content and validity of our measurements. The questionnaire was modified based on their feedback. A pilot test was conducted by 
sending out the questionnaire to ten senior managers whose companies were CCPIT members. The questionnaire was further revised based on their feedback.

The sample Chinese companies were randomly selected from the CCPIT's membership, and specifically those that had registered their outward FDI activities with Ministry of Commerce People’s Republic of China (MOFCOM). Our original sample consisted of 2,000 companies. The CCPIT's local representatives contacted these companies and sent them hard copies of the questionnaire. Of the 2,000 questionnaires sent out, a total of 365 questionnaires were received with a response rate of $18.25 \%$. A comparison of location and industries between the responding firms and non-responding ones suggested that the two groups of firms have similar distribution patterns in location and industries. After excluding the responses which either had missing information or were inapplicable, we were left with 181 observations. We excluded the firms who were wholly-owned foreign subsidiaries in China, given that these companies may have structure and operational processes not compatible with Chinese companies (Yiu, Lau, \& Bruton, 2007). Our final sample size was 181, including 45 state-owned enterprises (SOEs) and 136 private firms. These firms operate in 14 industries and have invested in 49 countries. The detailed information on subsidiary locations is presented in Table 1.

\section{INSERT TABLE 1 NEAR HERE}

\section{Variables and Measures}

Dependent variables. Following previous studies (Brouthers \& Xu, 2002; He, Tian, \& Chen, 2007; Lu, et al., 2010), a perceptual measure was used to proxy the performance of overseas subsidiaries of Chinese MNEs. Some researchers (He, Tian, \& Chen, 2007; Woodcock, Beamish, \& Makino, 1994) indicated that perceptual measures are appropriate when (1) companies are either unwilling or unable to 
provide sensitive accounting data; (2) variations in accounting approaches across countries is likely to hinder the reconciliation of differences; and/or (3) there are fluctuations in exchange rates between home and host countries. As a widely used construct in previous studies (Andersson, Forsgren, \& Holm, 2002; Birkinshaw, Hood, \& Young, 2005; He, Tian, \& Chen, 2007; Lu, et al., 2010), perceptual measures of performance have been proved to possess strong internal consistency and reliability (Cooper \& Artz, 1995; Ketokivi \& Schroeder, 2004).

We asked the respondents to evaluate the performance of their newly established overseas subsidiaries. This focus presents a number of advantages. First, respondents are more easily able to differentiate the focal overseas subsidiary from other overseas subsidiaries, and thus enhance the reliability of this measure. Second, all other key independent variables, i.e. expatriates, host country institutional quality and subsidiary autonomy, are directly related to the focal overseas subsidiary. Thus, the dependent variable and the key independent variables are compatible and focused on the same overseas subsidiary.

The variable consisted of three items on a seven-point scale (1=very dissatisfied; 7=very satisfied): (1) growth rate of sales; (2) growth rate of market share; and (3) growth rate of profit in the overseas subsidiary. The confirmatory factor analysis showed that the three items were loaded on a single factor, explaining $83.81 \%$ of the total variance. Cronbach's alpha reliability for perceived subsidiary performance was 0.90 , which is greater than 0.60 , a commonly acceptable level of reliability (Nunnally, 1978).

Independent variables. Based on Gong (2003a), Konopaske, et al. (2002) and Boyacigiller (1990), the level of expatriates was measured as the percentage of expatriates in the total workforce. In the survey instrument, the expatriate percentage 
was calculated by dividing the number of expatriates in a subsidiary by the total number of employees in the subsidiary. Traditionally, expatriates are considered individuals of any national origin who are transferred outside their home country (Edstrom \& Galbraith, 1977; Hocking, Brown, \& Harzing, 2004). In the context of Chinese MNEs, expatriates are considered synonymous with individuals of Chinese nationality who work outside China (Belderbos \& Heijltjes, 2005). According to Boyacigiller's (1990) terminology, we use the terms expatriate and parent-country national synonymously in the case of Chinese MNEs. Thus, the term, expatriate, is considered to be synonymous with parent-country national (PCN) and non-expatriate is considered to be synonymous with host-country national (HCN).

Mediating variables. We followed Williams and van Triest (2009) and assessed the level of autonomy based on the respondents' assessment regarding how much autonomy their management team was given to manage the subsidiary in terms of strategic and operational decision-making authority. Based on the evaluation and the practical insight of the managers from our pilot study, subsidiary autonomy is measured by four items along a seven-point scale (1=low; 7=high). The items are related to whether subsidiary managers have the authority to (1) decide the scope of their operations; (2) make budgetary and financial decisions; (3) hire, reward, promote and fire employees; and (4) undertake merger, acquisition and other capital operations. The factor analysis showed that the four items converged into a single factor, explaining $72.58 \%$ of the total variance. Cronbach's alpha for the measure was 0.87 , which exceeded the 0.60 cut-off-point (Nunnally, 1978).

Moderating variables. Based on previous studies (Cuervo-Cazurra \& Genc, 2008; Slangen \& Tulder, 2009), the objective measurement of the World Governance Indicators (WGI) in 2010 was used to capture the institutional quality of the host 
country. The WGI reports aggregate and individual governance indicators for 215 economies over the period 1996-2013 and includes six dimensions of government: (1) voice and accountability; (2) political stability and absence of violence; (3) government effectiveness; (4) regulatory quality; (5) rule of law and (6) control of corruption. We aggregated the six dimensions and labelled it as institutional quality of a host country where a Chinese company has conducted FDI. As each dimension has been constructed by compiling a number of primary and secondary data sources, the index offers reliable and comprehensive proxies for empirical studies (Oh \& Oetzel, 2011). The values of the WGI were rescaled by adding 2.5 so that the values in our sample range from 0 (low institutional quality) to 5 (high institutional quality), which helped facilitate the interpretation for the statistical significance of this variable (Cuervo-Cazurra \& Genc, 2008). The items were loaded on a single factor, explaining $84.59 \%$ of the variance. The reliability of the measurement was acknowledged with a Cronbach’s coefficient alpha of 0.92. Table 2 lists the measurement items above and summarizes the confirmatory factor analysis and internal consistency of the scales.

\section{INSERT TABLE 2 NEAR HERE}

Control variables. Several variables that may also affect subsidiary performance were controlled. First, we included a measure of subsidiary age, which was calculated as the number of years of operations within a host country (Delios \& Beamish, 2001; Fey \& Furu, 2008). Second, an MNE parent's age and size were included as control variables. They were calculated as the number of years in business and the natural logarithm of the number of employees, respectively (Wijk, Jansen, \& Lyles, 2008; Zhou, Wu, \& Luo, 2007). Third, because parent ownership types also matter in a transition economy (Wu \& Lin, 2010), we differentiated parent company types: state-owned enterprises and private-owned companies. A dummy variable with 
a value of 1 indicates that the parent company is a state-owned enterprise, and a value of 0 indicates a private-owned company. Finally, we created dummy variables to control for the industry sector in which a subsidiary locates.

\section{Common method bias}

As much of the data was collected from the same survey respondents, there may exist the potential for the occurrence of common method variance (Krishnan, Martin, \& Noorderhaven, 2006). We took a number of steps to minimize common method bias. First, multiple item constructs were used in our survey, since response biases are more likely to occur at the item level rather than at the construct level. In particular, the mediating and moderating effect is included in our hypotheses. This approach is effective in controlling for the issue of common method variance because complex relationships between the dependent and independent variables are not part of the respondents' theory-in-use (Chang, Witteloostuijn, \& Eden, 2010). Second, following previous studies (Kemery \& Dunlap, 1986; Podsakoff \& Organ, 1986), we performed Harman's single factor test. The result showed that the single factor model demonstrated a poor fit to the data. Third, the level of expatriates, as an independent variable, is a formative value rather than a self-perceived measure. In addition, we also used an objective measure for the institutional quality of host countries. Taken together, the potential extent of common method variance has been reduced substantially.

\section{Empirical Results}

The mean, standard deviations and correlations of the variables used in our analysis are presented in Table 3. It can be seen that all correlations among the independent variables are fairly low. To avoid potential multicollinearity, we centred the variables and computed the interaction terms as a product of the centred scores on the 
component variables in all analyses. Control variables were included in all regression analyses unless specified otherwise. To assess potential multicollinearity, the variance inflation factors (VIFs) of the matrices of independence variables and covariates were computed. None of the VIF values exceed the threshold of 10 (Neter, Wasserman, \& Kutner, 1990), indicating that multicollinearity is not a serious concern.

\section{INSERT TABLE 3 NEAR HERE}

A moderated mediation model can be tested in a number of ways (Edwards \& Lambert, 2007; MacKinnon, et al., 2002; Shrout \& Bolger, 2002). We follow Edwards and Lambert's (2007) procedure which integrates moderated regression analysis and path analysis to comprehensively analyse simultaneous moderation and mediation. This includes the first stage (between expatriates and subsidiary autonomy), the second stage (between subsidiary autonomy and subsidiary performance), a direct relationship between expatriates and subsidiary performance and an indirect effect through subsidiary autonomy, as well as the total effect at a particular level of the moderator (institutional quality). The detail of our analytical approach based on Edwards and Lambert's procedure is explained in Appendix A.

\section{INSERT TABLE 4 NEAR HERE}

Hypothesis 1 suggests that subsidiary autonomy mediates the relationship between expatriates and subsidiary performance, in which expatriates negatively affect subsidiary autonomy and a reduction in subsidiary autonomy leads to a decrease in subsidiary performance. Table 4 presents the regression results of Hypothesis 1 . The first-stage effect of expatriates on subsidiary autonomy in Model 1 is significantly negative $(\beta=-0.15, \quad \mathrm{p}<0.05)$, whereas the second-stage effect of subsidiary autonomy on subsidiary performance in Model 3 is positive and significant 
$(\beta=0.43, \quad \mathrm{p}<0.01)$. Furthermore, the direct effect of expatriates on subsidiary performance appears to be insignificant $(\beta=-0.12, \mathrm{p}>0.10)$. Therefore, there is a full, indirect-only mediation rather than a partial mediation (Zhao, Lynch, \& Chen, 2010) which indicates that the level of expatriates affects subsidiary autonomy but does not affect subsidiary performance directly. Therefore, subsidiary autonomy fully mediates the relationship between expatriates and subsidiary performance. This is confirmed by Sobel's test (Sobel, 1982), which is significant ( $\mathrm{z}=-6.95, \mathrm{p}<0.01)$. Consequently, Hypothesis 1 is supported.

The results in Model 2 and Model 5 show that the institutional quality of host countries positively moderates the negative impact of expatriates on subsidiary autonomy, but negatively moderates the positive impact of subsidiary autonomy on subsidiary performance. Thus, we receive support for Hypothesis 2 and Hypothesis 3.

\section{INSERT TABLE 5 NEAR HERE}

Table 5 summarises the results of further testing of Hypothesis 2 and Hypothesis 3. One standard deviation above or below the mean is used to indicate a high or low level of host-country institutional quality (Aiken \& West, 1991) which shows the interrelationship between expatriates, subsidiary autonomy and subsidiary performance at different levels of institutional quality. The first-stage moderation, which applies to the first-stage of the indirect effect, was significant $(0.55-(-0.17)=$ 0.72, $\mathrm{p}<0.05)$. The results indicate that the first-stage effect was $0.55(\mathrm{p}<0.05)$ in the host countries with a low level of institutional quality and $-0.17(\mathrm{p}<0.05)$ at a high level of host-country institutional quality. Thus, the results further confirm hypothesis 2, which suggests that the negative relationship between expatriates and subsidiary autonomy is stronger when institutional quality is high. The second-stage moderation, which applies to the second stage of the indirect effect, was significant $(0.70$ - 
$0.32=0.38, \mathrm{p}<0.05)$. The second-stage effect was $0.70(\mathrm{p}<0.05)$ in the host countries with a low level of institutional quality and $0.32(\mathrm{p}<0.05)$ at a high level of institutional quality. The results further support Hypothesis 3, which proposes that the positive relationship between subsidiary autonomy and subsidiary performance is stronger when institutional quality is low.

\section{INSERT FIGUREs 2 \& 3 NEAR HERE}

In order to have a better understanding on how institutional quality moderates the relationship between expatriates and subsidiary autonomy, and between subsidiary autonomy and subsidiary performance, we plotted the interaction effects in Figures 2 and 3. As shown in Figure 2, a high level of expatiate staffing is associated with a low level of autonomy in conditions of high host-country institutional quality. In Figure 3, it can be seen that greater autonomy is related to a high level of subsidiary performance in the host countries with low institutional quality. Both Figure 2 and Figure 3 further support Hypothesis 2 and Hypothesis 3 respectively.

In summary, we find that the level of subsidiary autonomy mediates the relationship between expatriates and subsidiary performance. In addition, the results also show that the effect of expatriates on subsidiary autonomy and the impact of subsidiary autonomy on subsidiary performance are moderated by host-country institutional quality.

\section{Discussion}

Based on a sample of Chinese MNEs, we have examined whether subsidiary autonomy mediates the impact of expatriates on subsidiary performance, and have considered the moderating effect of the institutional quality of host countries on the mediation mechanism. Our findings show that subsidiary autonomy, to a large extent, 
serves as a key mediator of the relationship between expatriates and subsidiary performance. By assigning expatriates to a subsidiary, the MNE parent may grant less autonomy to the subsidiary, which in turn reduces subsidiary performance. In other words, the power relationship between a subsidiary and its parent will shift toward the subsidiary when the level of expatriates decreases. The results differ from those of the majority of previous studies which reported a direct relationship between expatriation and subsidiary performance (Gaur, Delios, \& Singh, 2007; Gong, 2003a; Richards, 2001).

We further examined the interrelationship between expatriates, subsidiary autonomy and subsidiary performance given different levels of institutional quality. The findings indicate that the level of expatriates is used as a strategic control and resource exchange mechanism by EEMNEs. Specifically, high quality institutions in host countries induce EEMNE parents to send fewer expatriates, which results in a high level of subsidiary autonomy. This suggests that subsidiaries are motivated to engage in asset exploration in those host countries by granting them a high level of autonomy. There may be more resource exchanges between subsidiaries and local firms in host countries with well-established institutions. Thus, the negative relationship between expatriates and subsidiary autonomy is reinforced in host countries with high institutional quality. When subsidiaries are located in host countries with a high institutional quality, they may be able to employ more local employees and engage more closely with local suppliers and clients. The findings suggest that the impact of expatriates on subsidiary autonomy and subsidiary performance varies depending on host-country institutional quality. The nature of strategic asset-seeking outward FDI from emerging economies is also reflected in the relationship between the corporate parents and subsidiaries. When EEMNE 
subsidiaries operate in host countries with well-established institutions, they tend to establish a decentralised organizational structure which facilitates knowledge access and knowledge acquisition. For example, Lenovo acquired IBM’s PC division in 2004, and appointed the IBM’s Senior Vice President, Steve Ward, as the first foreign senior executive of the PC division of Lenovo in order to maintain knowledge access and customer acceptance (Luo \& Tung, 2007).

In contrast, the link between expatriates and subsidiary autonomy is reversed from negative to positive in host countries with lower institutional quality. Our findings suggest when subsidiaries operate in a host country with a high level of uncertainty and risk, they rely on both expatriates and subsidiary autonomy to respond to the frequent changes and to counterbalance the impact of the risky environment. The findings indicate that EEMNEs are likely to use more expatriates in host countries with low institution quality compared to those in the host countries with high institution quality. Thus, the level of expatriates not only acts as an internal control mechanism but also a means of intra-organisational or internal resource exchange between the MNE parent and subsidiary when external resource exchanges are unreliable and subject to high transaction cost due to great uncertainty in the host countries. In other words, subsidiaries operating in a host country with low institutional quality need to have additional autonomy and extra expatriates from headquarters. In this way, they are able to use intra-organisational resource flows to reduce their external dependence on local staffing. This finding also shows the importance of investigating the moderating effect of institutional quality. EEMNEs are sensitive to local institutional quality. EMNE parents support their subsidiaries in lower institutional quality countries with a higher level of expatriates and give them autonomy to run local subsidiaries according to the local environment, whereas in 
countries with higher institutional quality, parental firms tend to use a lower level of expatriates which leads to a higher level of autonomy.

Our findings show that there is a substitution effect between subsidiary autonomy and host-country institutional quality on subsidiary performance. Subsidiary autonomy becomes increasingly important in boosting performance in host countries with low institutional quality. The higher autonomy will enable effective local decision making to quickly respond to dynamic market changes and absorb uncertainty in such countries. In comparison, in countries with high institutional quality, subsidiary autonomy becomes less important in improving performance due to the benefits associated with a well-established institutional environment, such as reduced transaction costs and easier access to knowledge and resources. This study reveals that Chinese MNEs tend to assign more expatriates and grant more autonomy to the subsidiaries located in the countries with low institutional quality in order to enhance subsidiary performance.

\section{Contributions}

This study makes several contributions to the existing literature. Firstly, unlike previous studies which emphasised the effect of expatriates on performance in isolation, this study examines the interconnection between expatriates, subsidiary autonomy and subsidiary performance. Such an investigation enables us to provide new insights into how EEMNEs resolve the tension between expatriates and subsidiary autonomy in achieving desirable performance. The findings improve our understanding of the mechanisms through which the effect of expatriates on subsidiary performance is realized. Thus, our study fills an important research gap, given that much research in this domain has mainly focused on the direct link between expatriates and subsidiary performance. 
Secondly, while previous studies have predominantly focused on the impact of expatriates from well-established MNEs (Colakoglu \& Caligiuri, 2008; Gaur, Delios, \& Singh, 2007; Gong, 2003a), few have examined the role of expatriates from EEMNEs in a variety of host countries with diverse institutional qualities (Turcan \& Juho, 2012). Our study fills this gap by investigating the adaptive subsidiary control strategies of Chinese MNEs. The findings provide new insights into the contingent impact of host-county institutional quality on the links between expatriates, subsidiary autonomy and subsidiary performance.

Finally, this study is one of the first to investigate the indirect relationship between expatriates and subsidiary performance, taking account of the mediating role of autonomy granted to the subsidiary and the moderating role of the institutional quality of host countries. It extends the extant literature on the subsidiary performance of EEMNEs and provides much needed evidence on the complex relationship between expatriates, subsidiary autonomy and subsidiary performance, given the institutional quality of host countries. In particular, the findings enrich our understanding of how EEMNEs in the early stage of internationalization adjust expatriates and subsidiary autonomy to achieve overseas success in a variety of host countries.

\section{Managerial relevance}

Our findings have a number of managerial implications for practitioners. First, the evidence shows that subsidiary autonomy is an important mediator linking expatriates and subsidiary performance. Because of the negative relationship between expatriates and subsidiary autonomy, and the positive relationship between subsidiary autonomy and performance, foreign subsidiaries will be able to achieve a higher level of performance when they are granted a higher level of autonomy. This implies that 
EMNE parents should adopt a light touch approach by delegating their subsidiaries more power and authority for decision making to achieve overseas success.

Second, we have found that the relationship between expatriates, subsidiary autonomy and performance varies depending on host country institutional quality. Therefore, host-country institutional quality is an important factor that EMNE managers should consider when determining a suitable level of expatriate personnel. In other words, different institutional environments require a different balance of expatriates and subsidiary autonomy. Subsidiaries should be granted more autonomy together with an increased level of expatriates from headquarters when investing in host countries with under-developed institutions, but fewer expatriates and a higher level of autonomy when operating in host countries with high institutional quality.

In addition, we found that subsidiary autonomy relates more positively to subsidiary performance when institutional quality is lower, rather than higher. This suggests that EEMNEs should consider granting a higher level of subsidiary autonomy to the subsidiary in such circumstances as this can reduce a subsidiary's logistic costs and therefore increase efficiency. Subsidiary autonomy could be adopted as a strategic response to environmental uncertainty in those host countries with low institutional quality. EMNE managers should understand the importance of autonomy and flexibility when their subsidiaries are operating in an environment with a high uncertainty and political risk. They need to pay particular attention to intra-firm resource exchange and reducing organisational rigidity and external dependence.

\section{Limitations and future studies}

This study has several limitations that suggest future research directions. First, a perceptual measure of subsidiary performance is used in this study. Further work 
could use objective measurements to evaluate the effect of expatriates on the different dimensions of subsidiary performance. Second, our study only focused on Chinese MNEs. A comparative study using different countries of origin would help verify whether the findings are specific to the Chinese context. Third, expatriates are heterogeneous and vary in terms of skills and ability (Zhang \& Fan, 2014). Future research is needed to further test whether different types of expatriates affect subsidiary performance indirectly via subsidiary autonomy in host countries with different institutional environments. Furthermore, our study only tested one mediator and one moderator, namely subsidiary autonomy and the institutional quality of host countries. Future studies could examine whether other factors, such as knowledge transfer and cultural distance, also serve as mediating and moderating mechanisms. Doing so will further expand our understanding of the complex relationship between expatriates and subsidiary performance.

\section{Conclusion}

Adopting the resource dependence perspective, this paper examines the indirect effects of expatriates via subsidiary autonomy on subsidiary performance, based on a sample of Chinese MNEs operating in host countries with different levels of institutional quality. We find that assigning more expatriates enables the parent company to have tighter control on subsidiaries and reduce their autonomy, which in turn leads to a decrease in subsidiary performance. The results show that subsidiary autonomy mediates the relationship between expatriates and subsidiary performance. Such a relationship is moderated by host countries' institutional quality. The institutional quality of host countries reinforces the negative impact of expatriates on subsidiary autonomy, but reduces the importance of the latter on subsidiary performance. By examining the moderating effect of host-country institutional quality, 
this study sheds new light on the contingency of the institutional environment of a host country and EEMNEs' subsidiary performance. Thus, our study advances research on the post-entry organisational structure of EEMNEs by providing new insights into the role of expatriates and subsidiary autonomy as mechanisms of external dependence reduction and knowledge exploration in host countries with different institutional qualities.

\section{Acknowledgements}

The authors would like to thank the Guest Editors and two anonymous reviewers for their constructive comments. Financial support from the National Natural Science Foundation of China (NSFC 71572150) is gratefully acknowledged.

\section{References:}

Agarwal, S. \& Ramaswami, S. N. (1992). Choice of foreign market entry mode: Impact of ownership, location and internalization factors. Journal of International Business Studies, 23(1), 1-27.

Aharoni, Y., Tihanyi, L., \& Connelly, B. L. (2011). Managerial decision making in international business: A forty-five year retrospective Journal of World Business, 46(2), 135-142.

Aiken, L. S. \& West, S. G. (1991). Multiple regression: Testing and interpreting interactions. Thousand Oaks, CA: Sage.

Akhter, H. \& Lusch, R. F. (1998). Political risk and the evolution of control of foreign subsidiaries: Equity, earnings, and marketing mix. Journal of Global Marketing, 1(3), 109-128.

Ambos, T. C. \& Birkinshaw, J. (2010). Headquarters' attention and its effect on subsidiary performance. Management International Review, 50(4), 449-469.

Andersen, T. J. (2005). The performance effect of computer-mediated communication and decentralized strategic decision making. Journal of Business Research, 58(8), 1059-1067. 
Andersson, U., Forsgren, M., \& Holm, U. (2002). The strategic impact of external networks: Subsidiary performance and competence development in the multinational corporation. Strategic Management Journal, 23(11), 979-996.

Bartlett, C. A. \& Ghoshal, S. (1989). Managing across borders: The transactional solution. Boston: Harvard Business School Press.

Becker, B.E. \& Gerhart, B. (1996). The impact of human resource management on organizational performance: Progress and prospects. Academy of Management Journal, 39(4), 779-801.

Belderbos, R. A. \& Heijltjes, M. G. (2005). The determinants of expatriate staffing by Japanese multinationals in Asia: Control, learning and vertical business groups. Journal of International Business Studies, 36(3), 1-14.

Benito, G. R. G., Tomassen, S., Bonache-Perez, J., \& Pla-Barber, J. (2005). A transaction cost analysis of staffing decisions in international operations. Scandinavian Journal of Management, 21(1), 101-126.

Berry, H. (2006). Leaders, laggards and the pursuit of foreign knowledge. Strategic Management Journal, 27(2), 151-168.

Birkinshaw, J., Holm, U., Thilenius, P., \& Arvidsson, N. (2000). Consequences of perception gaps in th headquaters-subsidiary relationship. International Business Review, 9(3), 321-344.

Birkinshaw, J., Hood, N., \& Jonsson, S. (1998). Building firm-specific advantages in multinational corporations: The role of subsidiary initiative. Strategic Management Journal, 19(3), 221-241.

Birkinshaw, J., Hood, N., \& Young, S. (2005). Subsidiary entrepreneurship, internal and external competitive forces and subsidiary performance. International Business Review, 14(2), 227-248.

Boyacigiller, N. (1990). The role of expatriates in the management of interdependence, complexity and risk in multinational corporations. Journal of International Business Studies, 21(3), 357-381.

Brooke, M. Z. (1984). Centralization and autonomy: A study in organization behaviour. London and New York: Holt, Rinehart and Winston.

Brouthers, L. E. \& Xu, K. (2002). Product stereotypes, strategy and performance satisfaction: The case of Chinese exporters. Journal of International Business Studies, 33(4), 657-677.

Browman, S., Duncan, J., \& Weir, C. (2000). Decision-making autonomy in multinational corporation subsidiaries operating in Scotland. European Business Review, 12(3), 129-136. 
Buckley, P. J., Clegg, J. L., Cross, A. R., \& Voss, H. (2010). Whant can emerging markets learn from the outward direct investment policies of advanced economies? . In K. Sauvant, W. Maschek, \& G. McAllister (Eds), Foreign direct investment from emerging markets: The challenges ahead. London: Palgrave Macmillan.

Chalos, P. \& O'Connor, N. G. (2004). Determinants of the use of various control mechanisms in US-Chinese joint ventures. Accounting Organizations and Society, 29(7), 591-608.

Chang, S. J., Witteloostuijn, A. v., \& Eden, L. (2010). From the editors: Common method variance in international business research. Journal of International Business Studies, 41(2), 178-184.

Colakoglu, S. \& Caligiuri, P. (2008). Cultural distance, expatriate staffing and subsidiary performance: The case of US subsidiaries of multinational corporations. The International Journal of Human Resource Management, 19(2), 223-239.

Cooper, A. C. \& Artz, K. W. (1995). Determinants of satisfaction for entrepreneurs. Journal of Business Venturing, 10(6), 439-457.

Cuervo-Cazurra, A. \& Genc, M. (2008). Transforming disadvantages into advantages: Developing-country MNEs in the least developed countries. Journal of International Business Studies, 39(6), 957-979.

Cui, L., Meyer, K. E., \& Hu, H. W. (2014). What drives firms' intent to seek strategic assets by foreign direct investment? A study of emerging economy firms. Journal of World Business, 49(4), 488-501.

Davis, G. F. \& Cobb, J. A. (2010). Resource dependence theory: past and future. In Schoonhoven, C. B., \& Dobbin, F. (Eds), Stanford's organization theory renaissance,1970-2000. London: Emerald, 28, 21-42.

Delios, A. \& Beamish, P. W. (1999). Ownership strategt of Japanese firms: Transactional, institutional, and experience influences. Strategic Management Journal, 20(10), 915-933.

Delios, A. \& Beamish, P. W. (2001). Survival profitability: the roles of experience and intangible assets in foreign subsidiary performance. Academy of Management Journal, 44(5), 1028-1038.

Delios, A. \& Bjorkman, I. (2000). Expatriate staffing in foreign subsidiaries of Japanese multinational corporations in the PRC and the United States'. International Journal of Human Resource Management, 11(2), 278-299.

Delios, A. \& Henisz, W. J. (2000). Japanese firms' investment strategies in emerging economies. Academy of Management Journal, 43(3), 305-323.

Delios, A. \& Henisz, W. J. (2003). Political hazards and the sequence of entry by Japanese firms. Journal of International Business Studies, 34(3), 227-241. 
Edstrom, A. \& Galbraith, J. R. (1977). Transfer of managers as a coordination and control strategy in multinational organizations. Administrative Science Quarterly, 22(2), 248-263.

Edwards, J. R. \& Lambert, L. S. (2007). Methods for integrating moderation and mediation: A general analytical framework using moderated path analysis. Psychological Methods, 12(1), 1-22.

Edwards, R., Ahmad, A., \& Moss, S. (2002). Subsidiary autonomy: The case of multinational subsidiaries in Malaysia. Journal of International Business Studies, 33(1), 183-191.

Egelhoff, W. G. (1984). Patterns of control in U.S., UK, and European multinational corporations. Journal of International Business Studies, 15(3), 73-83.

Fan, D., Nyland, C., \& Zhu, C. (2008). Strategic implications of global integration and local responsiveness for Chinese multinationals: An area for future study. Management Research News, 31(12), 922-940.

Fang, Y., Jiang, G., Makino, S., \& Beamish, P. (2010). Multinational firm knowledge, use of expatriates, and foreign subsidiary performance. Journal of Management Studies, 47(1), 27-54.

Feinberg, S. \& Gupta, A. (2009). MNC subsidiaries and country risk: Internalization as a safeguard against weak external institutions. Academy of Management Journal, 52(2), 381-399.

Fey, C. F. \& Furu, P. (2008). Top management incentive compensation and knowledge sharing in multinational corporations. Strategic Management Journal, 29(12), 1301-1323.

Gammelgaard, J., McDonald, F., Stephan, A., Tuselmann, H., \& Dorrenbacher, C. (2012). The impact of increases in subsidiary autonomy and network relationships on performance. International Business Review, 21(6), 1158-1172.

Gaur, A. S., Delios, A., \& Singh, K. (2007). Institutional environements, staffing strategies, and subsidiary performance. Journal of Management, 33(4), 611-636.

Gomez, C. \& Werner, S. (2004). The effect of institutional and strategic forces on management style in subsidiaries of U.S. MNCs in Mexico. Journal of Business Research, 57(10), 1135-1144.

Gong, Y. (2003a). Subsidiary staffing in multinational enterprises: Agency, resources, and performance. The Academy of Management Journal, 46(6), 728-739.

Gong, Y. (2003b). Toward a dynamic process model of staffing composition and subsidiary outcomes in multinational enterprises. Journal of Management, 29(2), 259280. 
Gupta, A. K. \& Govindarajan, V. (1991). Knowledge flows and the structure of control with multinational corporations. Academy of Management Review, 16(4), 768792.

He, Y., Tian, Z., \& Chen, Y. (2007). Performance implication of nonmarket strategy in China. Asia Pacific Journal of Management, 24(2), 151-169.

Henisz, W. J. (2000). The institutional environment for multinational investment. Journal of Law, Economics, and Organization, 16(2), 334-364.

Hocking, J. B., Brown, M., \& Harzing, A. W. (2004). A knowledge transfer perspective of strategic assignment purposes and their path-dependent outcomes. International Journal of Human Resource Management, 15(3), 565-586.

Hoskisson, R. E., Eden, L., Lau, C. M., \& Wright, M. (2000). Stratedy in Emerging Economies. Academy of Management Journal, 43(3), 249-267.

Jensen, R. J. \& Szulanski, G. (2004). Stickiness and the adaptation of organizational practices in cross-border knowledge transfers. Journal of International Business Studies, 35(6), 508-523.

Kawai, N. \& Strange, R. (2014). Subsidiary autonomy and performance in Japanese multinationals in Europe. International Business Review, 23(3), 504-515.

Kemery, E. R. \& Dunlap, W. P. (1986). Partialling factor scores does not control method variance: A reply to Podsakoff and Todor. Journal of Management, 12(4), 525-544.

Ketokivi, M. \& Schroeder, R. (2004). Perceptual measures of performance: Fact or fiction. Journal of Operations Management, 22(3), 247-264.

Kobrin, S. J. (1982). Managing political risk assessment: Strategic responses to environmental changes. University of California Press: Berkeley, CA.

Konopaske, R., Werner, S., \& Neupert, K. E. (2002). Entry mode strategy and performance, the role of FDI staffing. Journal of Business Research, 55(9), 759-770.

Krishnan, R., Martin, X., \& Noorderhaven, N. G. (2006). When does trust matter to alliance performance? Academy of Management Journal, 49(5), 894-917.

Law, K. S., Song, L. J., Wong, C., \& Chen, D. (2009). The antecedents and consequences of successful localization. Journal of International Business Studies, 40(8), 1359-1373.

Lewin, A., Weigelt, C. B., \& Emery, J. D. (2004). Adapation and selection in strategy and change: Perspectives on strategic change in organizations. In M.S. Poole \& A.H. Van de Ven (Eds.), Handbook of organizational change and innovation. Oxford University Press, 108-160. 
Liu, X., Gao, L., Lu, J., \& Lioliou, E. (2016). Environmental risks, localization and the overseas subsidiary performance of MNEs from an emerging economy. Journal of World Business, 51(3), 356-368.

Lorange, P. (1986). Human resource management in multinational cooperative ventures. Human Resource Management, 25(1), 133-148.

Lu, J., Liu, X., Wright, M., \& Filatotchev, I. (2014). FDI location choices of Chinese firms: The moderating effects of home country government support and host country institutions on internationalization experience. Journal of International Business Studies, 45(4), 428-449.

Lu, Y., Zhou, L., Bruton, G., \& Li, W. (2010). Capabilities as a mediator linking resources and the international performance of entrepreneurial firms in an emerging economy. Journal of International Business Studies, 27(4), 409-429.

Luo, Y. (2003). Market-seeking MNEs in an emerging market: How parent-subsidiary links shape overseas success. Journal of International Business Studies, 34(3), 290309.

Luo, Y. \& Tung, R. L. (2007). International expansion of emerging market enterprises: A springboard perspective. Journal of International Business Studies, 38(4), 481-498.

Luo, Y., Xue, Z., \& Han, B. (2010). How emerging market governments promote outward FDI: Experience from China. Journal of World Business, 45(1), 68-79.

MacKinnon, D. P., Lockwood, C. M., Hoffman, J. M., West, S. G., \& Sheets, V. (2002). A comparison of methods to test mediation and other intervening variable effects. Psychological Methods, 7(1), 83-104.

McDonald, F., Warhurst, S., \& Allen, M. (2008). Autonomy, embeddedness and the performance of foreign owned subsidiaries. Multinational Business Review, 16(3), 7392.

McEvily, B. \& Zaheer, A. (1999). Bridging ties: a source of firm heterogeneity in competitive capabilities. Strategic Management Journal, 20(12), 1133-1156.

Meyer, K. E. \& Sinani, E. (2009). When and where does foreign direct investment generate positive spillovers? A meta-analysis. Journal of International Business Studies, 40(7), 1075-1094.

Moran, T. (1985). Multinational corporations: The political economy of foreign direct investment. Lexington Books: Lexington, MA.

Nell, P. C. \& Andersson, U. (2012). The complexity of the business network context and its effect on subsidiary relational (over-) embeddedness. International Business Review, 21(6), 1087-1098. 
Neter, J., Wasserman, W., \& Kutner, M. H. (1990). Applied linear statistical models. 3rd Edn, Irwin: Homewood, IL.

Newburry, W., Zeria, Y., \& Yeheskel, O. (2003). Autonomy and effectiveness of equity international joint ventures (IJVs) in China. International Business Review, 12(4), 395-419.

Nicholson, R. \& Salaber, J. (2013). The motives and performance of cross-border acquirers from emerging economies: Comparison between Chinese and Indian firms. International Business Review, 22(6), 963-980.

North, D. C. (1990). Institutions, institutional change, and economic performance. Cambridge, MA: Harvard University Press.

Nunnally, J. (1978). Phychometric theory (2nd ed.). New York: MCGraw-Hill.

O'Donnell, S. (2000). Managing foreign owned subsidiaries: Agents of headquaters or an independent network? Strategic Management Journal, 21(5), 525-548.

Oh, C. H. \& Oetzel, J. (2011). Multinationals' response to major disasters: How does subsidiary investment vary in response to the type of disaster and the quality of country governance? Strategic Management Journal, 32(6), 658-681.

Pfeffer, J. \& Salancik, G. R. (1978). The external control of organizations: A resource dependence perspective. New York: Harper \& Row.

Pingdom. (2008). Internet 2008 in numbers.

Podsakoff, P. M. \& Organ, D. W. (1986). Self-reports in organizational research: problems and prospects. Journal of Management, 12(4), 531-544.

Rangan, S. \& Drummond, A. (2011). The problem of control and the role of homehost ties in explaining multinationals' foreign operations, competitiveness, and performance. Global Strategy Journal, 1(3-4), 362-376.

Richards, M. (2001). US multinational staffing practices and implications for subsidiary performance in the UK and Thailand. Thunderbird International Business Review, 43(2), 225-242.

Schwens, C., Eiche, J., \& Kabst, R. (2011). The moderating impact of informal institutional distance and formal institutional risk on SME entry mode choice. Journal of Management Studies, 2(48), 330-351.

Selmer, J. (2004). Expatriates' hesiation and the localization of Western business operations in China. International Journal of Human Resource Management, 15(6), 1094-1108. 
Shrout, P. E. \& Bolger, N. (2002). Mediation in experimental and non-experimental studies: New procedures and recommendations. Psychological Methods, 7(4), 422445.

Simonin, B. L. (1999). Ambiguity and the process of knowledge transfer in strategic alliances. Strategic Management Journal, 20(7), 595-623.

Slangen, A. H. \& Tulder, R. J. v. (2009). Culture distance, political risk, or government quality? Towards a more accurate conceptualization and measurement of external uncertainty in foreign entry mode research. International Business Review, 18(3), 279-291.

Slangen, A. H. L. \& Hennart, J. F. (2008). Do multinationals really perfer to enter culturally distant countries through greenfields rather than through acquisitions? The role of parent experience and subsidiary autonomy. Journal of International Business Studies, 39(3), 472-490.

Sobel, M. E. (1982). Asymptotic confidence intervals for indirect effects in structural equation models. In S. Leinhart (Ed), Sociological methodology. San Francisco: Jossey-Bass, 290-312.

Steers, R. M. \& Nardon, L. (2006). Managing in the global economy. New York: $M E$ Sharpe.

Tan, D. \& Mahoney, J. T. (2006). Why a multinational firm chooses expatriates: intergrating resource-based, agency, and transaction cost perspectives. Journal of Management Studies, 43(3), 457-484.

Tran, Y., Mahnke, V., \& Ambos, B. (2010). The effect of quantity quality and timing of headquaters-initiated knowledge flows on subsidiary performance. Management International Review, 50(4), 493-511.

Tung, R. (2007). The human resource challenge to outward foreign direct investment aspirations from emerging economies: The case of China. International Journal of Human Resource Management, 18(5), 868-889.

Turcan, R. V. \& Juho, A. (2012). What happens to international new ventures beyond the start-up phase? The evidence from Finnish software companies. European International Business Academy, 38th Annual Conference.

UNCTD. (2006). World investment report-FDI from developing and transition economies: Implications for development. New York and Geneva.

Wall, T. D. \& Wood, S. J. (2005). The romance of human resource management and business performance, and the case for big science, Human Relations, 58(4), 429-462.

Wang, L., Luo, Y., Lu, X., Sun, J., \& Maksimov, V. (2014). Aotonomy delegation to foreign subsidiaries: An enabling mechanism for emerging-market multinationals. Journal of International Business Studies, 45(2), 111-130. 
Wang, P., Tong, T. W., \& Koh, C. P. (2004). An integrated model of knowledge transfer from MNC parent to China subsidiary Journal of World Business, 39(2), 168182.

Wang, S., Tong, T. W., Chen, G., \& Kim, H. (2009). Expatriate utilization and foreign direct investment performance: The mediating role of knowledge transfer. Journal of Management, 35(5), 1181-1206.

Wijk, R. V., Jansen, J. P., \& Lyles, M. A. (2008). Inter- and intra-organizational knowledge transfer: A meta-analytic review and assessment of its antecedents and consequences. Journal of Management Studies, 45(4), 815-838.

Williams, C. \& Triest, S. v. (2009). The impact of corporate and national cultures on decentralization in multinational corporations. International Business Review, 18(2), 156-167.

Williamson, O. E. (1985). The economic institutions of capitalism: Firms, markets, relational contracting. New York: The Free Press.

WIR. (2014). World Investment Report 2014: FDI from developing and transtion economies: Implications for developement. United Nations: New York.

Woodcock, C. P., Beamish, P. W., \& Makino, S. (1994). Ownership-based entry mode strategies and international performance. Journal of International Business Studies, 25(2), 253-273.

Wright, M., Filatotchev, I., Hoskisson, R. E., \& Peng, M. W. (2005). Strategy research in emerging economies: Challenging the conventional wisdom. Journal of Management Studies, 42(1), 1-33.

Wu, W. \& Lin, C. (2010). Experience, environment, and subsidiary performance in high-tech MNEs. Journal of Business Research, 63(12), 1301-1309.

Xu, D., Pan, Y., \& Beamish, P. W. (2004). The effect of regulative and normative distances on MNE ownership and expatriate strategies. Management International Review, 44(3), 285-307.

Yildiz, H. E. \& Fey, C. F. (2012). The liability of foreigness reconsidered: New insights from the alternative research context of transforming economies. International Business Review, 21(2), 269-280.

Yiu, D. W., Lau, C. M., \& Bruton, G. D. (2007). International venturing by emerging economy firms: the effects of firm capabilities, home country networks, and corporate enterpreneurship. Journal of International Business Studies, 38(4), 519-540.

Young, S. \& Tavares, A. (2004). Centralization and autonomy: Back to the future. International Business Review, 13(3), 215-237. 
Zhang, M. \& Fan, D. (2014). Expatriate skills training strategies of Chinese multinationals operating in Australia. Asia-Pacific Journal of Human Resources, 52(1), 60-76.

Zhao, X., Lynch, J. G., \& Chen, Q. (2010). Reconsidering Baron and Kenny: Myths and truths about mediation analysis. Journal of Consumer Research, 37(2), 197-206.

Zhou, K. Z., Tse, D. K., \& Li, J. (2006). Organizational change in emerging economies: Drivers and consequences. Journal of International Business Studies, 37(2), 248-263.

Zhou, L., Wu, W., \& Luo, X. (2007). Internationalization and the performance of born-global SMEs: The mediating role of social networks. Journal of International Business Studies, 38(4), 673-690.

Zhu, C., Cooper, B., Cieri, H. L. D., Thomson, S. B., \& Zhao, S. (2008). Development of HR practices in transitional economies: Evidence from China. International Journal of Human Resource Management, 19(5), 840-855. 


\section{Appendix A:}

We tested the hypothesis on the mediating effects of subsidiary autonomy on the relationship between expatriates and subsidiary performance based on Edwards and Lambert's constrained nonlinear regression module (Edwards \& Lambert, 2007). A first and second-stage moderated mediation model is involved in estimating the following two equations:

$$
\begin{aligned}
& \mathbf{M}=\alpha_{05}+\alpha_{X 5} X+\alpha_{Z 5} Z+\alpha_{X Z 5} X Z+\varepsilon_{M 5} \\
& \mathbf{Y}=\beta_{020}+\beta_{X 20} X+\beta_{M 20} M+\beta_{Z 20} Z+\beta_{X Z 20} X Z+\beta_{M Z 20} M Z+\varepsilon_{Y 20}
\end{aligned}
$$

where $\mathrm{X}$ is expatriates; $\mathrm{Z}$ is institutional quality; $\mathrm{XZ}$ is the product of expatriates and institutional quality; $\mathrm{M}$ is a subsidiary autonomy; $\mathrm{MZ}$ is the product of subsidiary autonomy and institutional quality; and Y is subsidiary performance.

Equation 3 is obtained by substituting Equation 1 into Equation 2:

$$
\begin{array}{r}
\mathrm{Y}=\left[\beta_{020}+\beta_{Z 20} Z+\left(\alpha_{05}+\alpha_{Z 5} Z\right)\left(\beta_{M 20}+\beta_{M Z 20} Z\right)\right]+\left[\left(\beta_{X 20}+\beta_{X Z 20} Z\right)+\right. \\
\left.\left(\alpha_{X 5}+\alpha_{X Z 5} Z\right)\left(\beta_{M 20}+\beta_{M Z 20} Z\right)\right] X+\varepsilon_{Y 20}+\beta_{M 20} \varepsilon_{M 5}+\beta_{M Z 20} Z \varepsilon_{M 5}
\end{array}
$$

In Equation 3, the direct effect of $\mathrm{X}$ (expatriates) on $\mathrm{Y}$ (subsidiary performance) corresponds to the term $\left(\beta_{1} X 20+\beta_{1} X Z 20 Z\right)$, which varies by $\mathrm{Z}$ (institutional quality). The indirect effect of $\mathrm{X}$ on $\mathrm{Y}$ corresponds to $\left(\alpha_{X 5}+\alpha_{X Z 5} Z\right)\left(\beta_{M 20}+\beta_{M Z 20} Z\right)$, which also varies by $Z$. The term $\left(\alpha_{X 5}+\alpha_{X Z 5} Z\right)$ captures the first-stage moderation of the indirect effect, and the term $\left(\beta_{M 20}+\beta_{M z 20} Z\right)$ captures the second-stage moderation of the indirect effect. 
Table 1: The locations of Chinese overseas subsidiaries

\begin{tabular}{l}
\hline \multicolumn{1}{c}{ Investment Destinations: host countries } \\
\hline Algeria, Australia, Austria, Bengal, Brazil, Botswana, Burkina Faso, Cambodia, Canada, Congo, \\
Ecuador, Equatorial Guinea, Ethiopia, France, Gabon, Germany, Ghana, Guinea, Hungary, Iran, India, \\
Indonesia, Japan, Kazakhstan, Kenya, Kyrgyzstan, Laos, Malaysia, Mongolia, Mozambique, \\
Netherlands, Nigeria, Peru, Philippines, Russia, Saudi Arabia, Singapore, South Africa, South Korea, \\
Sudan, Tanzania, the UK, the USA, Turkey, Uganda, Ukraine, United Arab Emirates, Uzbekistan, \\
Vietnam
\end{tabular}


Table 2: Measurement scales and factor loadings

\begin{tabular}{|c|c|c|c|c|}
\hline Constructs & Measurement items & $\begin{array}{l}\text { Factor } \\
\text { loading }\end{array}$ & $\begin{array}{c}\text { Variance } \\
\text { explained } \\
(\%) \\
\end{array}$ & $\begin{array}{c}\text { Cronbach’ } \\
\text { s alphas }\end{array}$ \\
\hline Subsidiary performance & & & 83.81 & $\alpha=0.90$ \\
\hline \multirow[t]{3}{*}{$\mathrm{CR}=0.89, \mathrm{AVE}=0.74$} & Sale growth & 0.84 & & \\
\hline & - $\quad$ Local market share growth & 0.90 & & \\
\hline & - $\quad$ Sales margin growth & 0.83 & & \\
\hline Subsidiary autonomy & & & 72.58 & $\alpha=0.87$ \\
\hline \multirow[t]{4}{*}{$\mathrm{CR}=0.88, \mathrm{AVE}=0.64$} & Right to decide the scope of operations by heads of overseas subsidiary & 0.82 & & \\
\hline & - $\quad$ Right to decide budgetary and financial decisions by heads of overseas subsidiary & 0.87 & & \\
\hline & - $\quad$ Right to hire, reward, promote and fire employees by heads of overseas subsidiary & 0.87 & & \\
\hline & - $\quad$ Right to do mergers and acquisitions and other capital operations by overseas subsidiary & 0.63 & & \\
\hline Institutional quality & & & 84.59 & $\alpha=0.92$ \\
\hline \multirow[t]{6}{*}{$\mathrm{CR}=0.96, \mathrm{AVE}=0.81$} & Voice and Accountability & 0.73 & & \\
\hline & Political Stability and Absence of Violence/Terrorism & 0.81 & & \\
\hline & - $\quad$ Government Effectiveness & 0.96 & & \\
\hline & • $\quad$ Regulatory Quality & 0.95 & & \\
\hline & Rule of Law & 0.97 & & \\
\hline & Control of Corruption & 0.94 & & \\
\hline
\end{tabular}

CR, composite reliability; AVE, average variance extracted 
Table 3: Descriptive statistic and correlations

\begin{tabular}{|c|c|c|c|c|c|c|c|c|c|c|c|}
\hline Variables & Mean & s.d. & 1 & 2 & 3 & 4 & 5 & 6 & 7 & 8 & 9 \\
\hline 1. MNC parent age & 20.17 & 15.09 & 1.00 & & & & & & & & \\
\hline 2. Subsidiary age & 5.18 & 2.88 & 0.03 & 1.00 & & & & & & & \\
\hline 3. MNC parent size & 2.81 & 0.92 & $0.41^{* *}$ & 0.02 & 1.00 & & & & & & \\
\hline 4. Parent ownership & 0.25 & 0.43 & $0.31^{* *}$ & -0.03 & 0.07 & 1.00 & & & & & \\
\hline 5. Subsidiary Industry & 0.25 & 0.43 & 0.07 & $0.17^{*}$ & $0.19^{*}$ & -0.07 & 1.00 & & & & \\
\hline 6. Subsidiary performance & 4.48 & 1.01 & 0.06 & 0.07 & $0.26^{* *}$ & -0.11 & $0.19^{* *}$ & 1.00 & & & \\
\hline 7. Expatriates & 46.37 & 35.17 & 0.12 & -0.09 & 0.12 & $0.18^{*}$ & -0.04 & -0.13 & 1.00 & & \\
\hline 8. Subsidiary autonomy & 4.53 & 1.15 & -0.01 & 0.04 & $0.15^{*}$ & -0.14 & $0.24^{* *}$ & $0.43^{* *}$ & $-0.15^{*}$ & 1.00 & \\
\hline 9. Institutional quality & 2.93 & 0.98 & -0.07 & 0.13 & $-0.31^{* *}$ & 0.01 & -0.13 & $-0.22^{* *}$ & -0.07 & -0.10 & 1.00 \\
\hline
\end{tabular}

${ }^{*} \mathrm{p}<0.05 ;{ }^{*} \mathrm{p}<0.01$ 
Table 4: Coefficient estimates for the moderated mediation model for subsidiary performance

\begin{tabular}{|c|c|c|c|c|c|c|c|c|c|c|c|c|}
\hline & \multicolumn{6}{|c|}{ First stage $($ dependent variable $=\mathrm{SA})$} & \multicolumn{6}{|c|}{ Second stage (dependent variable = performance) } \\
\hline & \multicolumn{3}{|c|}{ Module 1} & \multicolumn{3}{|c|}{ Module 2} & \multicolumn{3}{|c|}{ Module 3} & \multicolumn{3}{|c|}{ Module 4} \\
\hline & $\alpha$ & SE & $\mathrm{t}$ & $\alpha$ & SE & $\mathrm{t}$ & $\alpha$ & SE & $\mathrm{t}$ & $\alpha$ & SE & $\mathrm{t}$ \\
\hline Subsidiary age & 0.00 & 0.03 & 0.00 & 0.00 & 0.03 & -0.03 & 0.08 & 0.02 & 1.12 & 0.07 & 0.02 & 1.12 \\
\hline MNC parent size & -0.02 & 0.08 & -0.28 & -0.03 & 0.08 & -0.39 & 0.10 & 0.07 & 1.42 & 0.09 & 0.07 & 1.34 \\
\hline Ownership & -0.12 & 0.17 & -1.52 & -0.10 & 0.17 & -1.47 & -0.07 & 0.14 & -1.07 & -0.07 & 0.14 & -1.07 \\
\hline Industry & 0.23 & 0.18 & $2.97^{* *}$ & 0.23 & 0.18 & $3.30^{* *}$ & 0.04 & 0.14 & 0.59 & 0.05 & 0.14 & 0.82 \\
\hline Subsidiary autonomy & & & & & & & 0.43 & 0.08 & $5.08^{* *}$ & 0.51 & 0.08 & $6.03^{* *}$ \\
\hline Expatriates $\mathrm{x}$ institutional quality & & & & -0.37 & 0.00 & $-5.11^{* *}$ & & & & -0.20 & 0.00 & $-3.10^{* *}$ \\
\hline Subsidiary autonomy $\mathrm{x}$ institutional quality & & & & & & & & & & -0.19 & 0.01 & $-2.94^{*}$ \\
\hline $\mathrm{R}^{2}$ & & 0.10 & & & 0.24 & & & 0.26 & & & 0.38 & \\
\hline
\end{tabular}

Note: $\mathrm{SA}=$ subsidiary autonomy; $\mathrm{SE}=$ standard error.

${ }^{*} \mathrm{p}<0.05 ;{ }^{* *} \mathrm{p}<0.01$; 
Table 5: The effects of the relationship between expatriates and subsidiary autonomy and between subsidiary autonomy and subsidiary performance at different levels of institutional quality

\begin{tabular}{|c|c|c|c|}
\hline Model & Institutional quality & First stage & Second stage \\
\hline \multirow[t]{3}{*}{ E-SCM-Performance } & Low & $0.55^{*}$ & $0.70^{*}$ \\
\hline & High & $-0.17^{*}$ & $0.32^{*}$ \\
\hline & Difference & $0.72^{*}$ & $0.38^{*}$ \\
\hline
\end{tabular}

Note. The first and second-stage simple effects for low and high levels of institutional quality were calculated with coefficient estimates from Table 3. Institutional quality was +0.98 (i.e. one SD above the mean) and -0.98 (i.e. one SD below the mean) for the high and low levels of institutional quality, respectively. Differences in simple effects were calculated by subtracting the effects for high institutional quality from the effects for low institutional quality. Significant tests for the first and second-stage simple effects are equivalent to tests for the coefficients of the interaction terms in the first and second-stage model in Table 4, respectively.

$\mathrm{E}=$ expatriates; $\mathrm{SCM}=$ subsidiary autonomy.

${ }^{*} \mathrm{p}<0.05 ; * * \mathrm{p}<0.01$ 
Figure 1. The conceptual framework

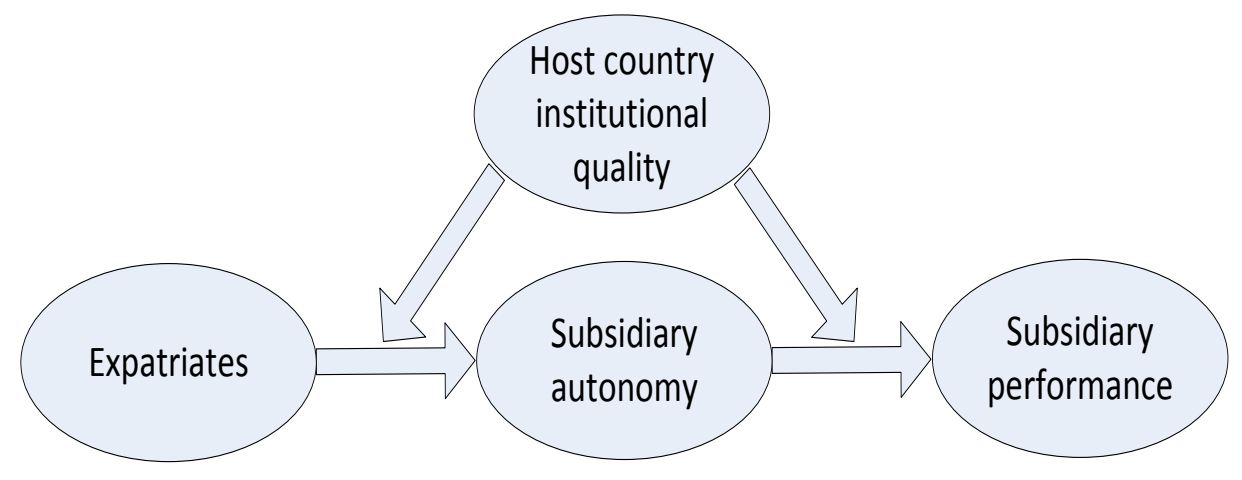

Figure 2: The effect of expatriates on subsidiary autonomy in host countries with high and low levels of institutional quality

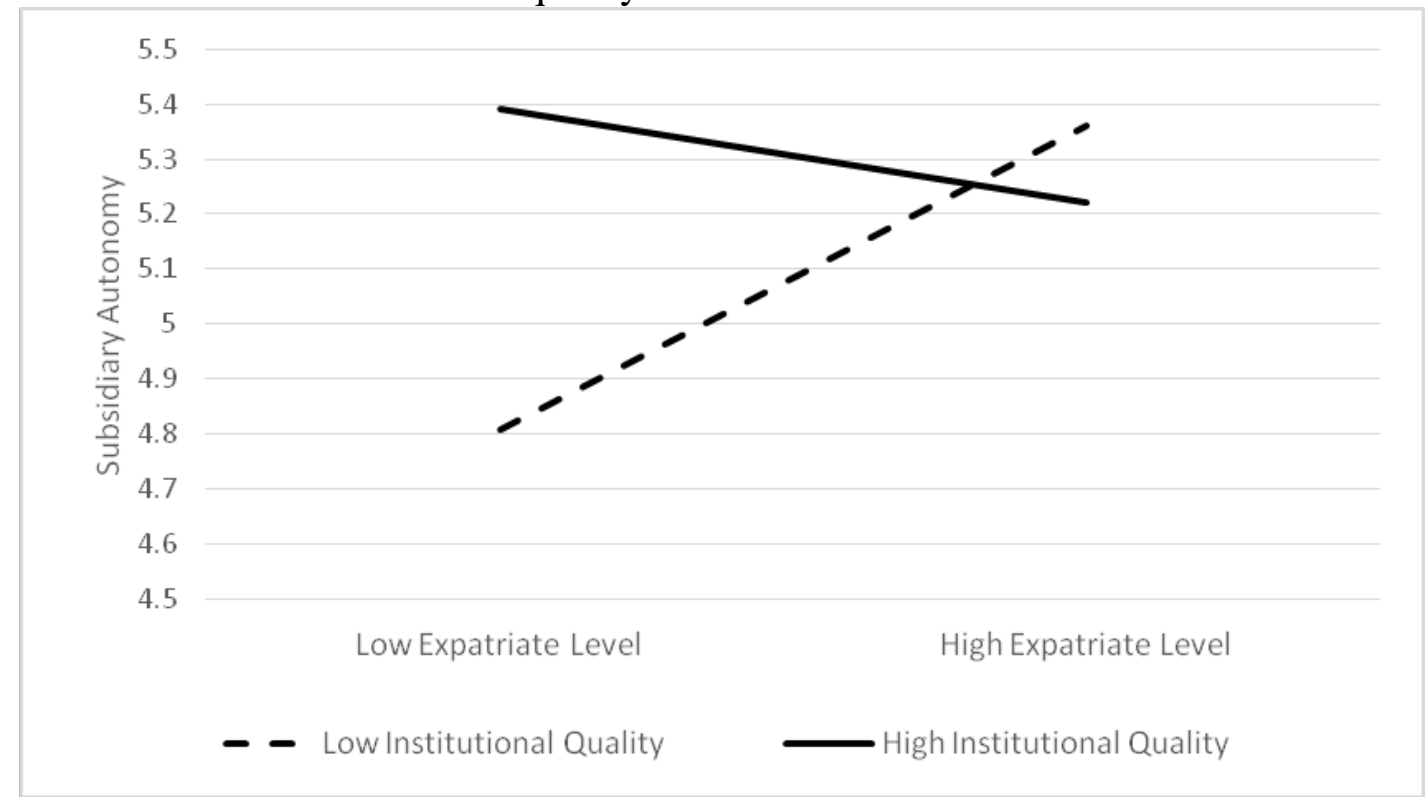


Figure 3: The effect of subsidiary autonomy on subsidiary performance in host countries with high and low levels of institutional quality

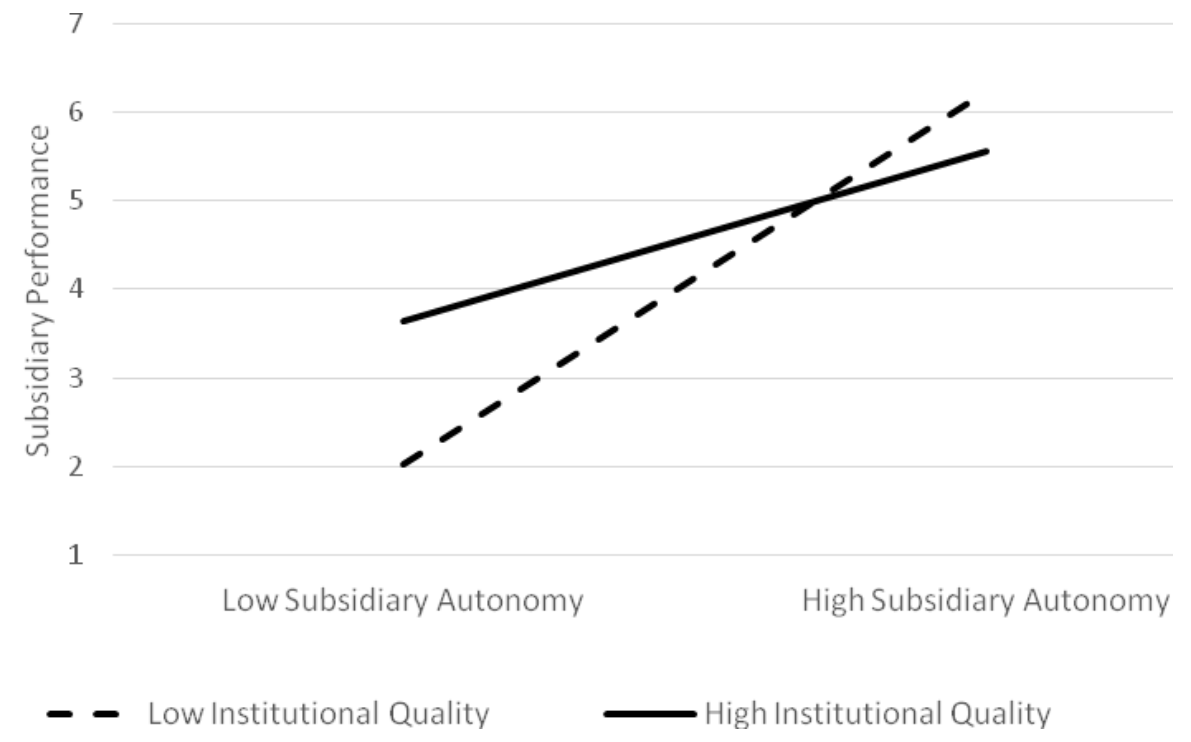

